\title{
ISOLATION OF CARBOXYPEPTIDASE III FROM MALTED BARLEY BY AFFINITY CHROMATOGRAPHY
}

\author{
by \\ KLAUS BREDDAM and STEEN BECH SøRENSEN \\ Department of Chemistry, Carlsberg Laboratory, \\ Gamle Carlsberg Vej 10, DK-2500 Copenhagen Valby
}

Keywords: Carboxypeptidase, barley, malt, affinity chromatography

\begin{abstract}
A novel serine carboxypeptidase has been isolated from malted barley by affinity chromatography. The enzyme has been termed malt carboxypeptidase III in correspondence with the nomenclature suggested by MiKOLA to distinguish it from the previously isolated carboxypeptidases I and II. Malt carboxypeptidase III is a monomer with a molecular weight around 48,000 , composed of a single peptide chain, two glucosamine residues and $2 \%$ neutral sugar. The peptide chain is $\mathrm{N}$-terminally blocked and it contains a single unblocked cysteinyl residue.

Like other serine carboxypeptidases malt carboxypeptidase III exhibits peptidase activity with an acidic $\mathrm{pH}$ optimum. However, unlike other such enzymes, the $\mathrm{pH}$ optimum for the esterase activity is also acidic. The kinetic analysis showed that this probably is due to deprotonation of an ionizable group with a $\mathrm{pK}_{\mathrm{a}}$ around 7 which controls the conformation of the active site. The transition of the active acidic form into the inactive basic form is reversible but time dependent.

Malt carboxypeptidase III exhibits a preference for substrates with Phe, Met, Ile and Val in the $\mathrm{P}_{1}^{\prime}$ position and Phe, Leu, Met and Ala in the $P_{1}$ position. The enzyme is inhibited by diisopropyl phosphorofluoridate, mercuric ions and various organomercuric compounds.
\end{abstract}

\section{INTRODUCTION}

Resting barley grains contain large amounts of storage proteins which are degraded during germination by proteolytic enzymes induced at this stage (11). The serine carboxypeptidases play an important role in this process and Mikola $(17,18,19)$ has presented evidence for the presence in malt of five such enzymes with complementary specificites. In this laboratory two of these have been isolated by affinity chromatography and their enzymatic properties and sequences have been determined $(2,3,4,6$, $7,23,24)$. The isolation and characterization of CPD- $\mathrm{M}_{\text {III }}$ is reported here.

Abbreviations: $\mathrm{BS}=$ benzyl succinic acid; $\mathrm{Bz}=$ benzoyl; $\mathrm{Bzl}=$ benzyl; CABS-Sepharose $=[\mathrm{N}$-(z-aminocaproyl)-paminobenzyl] succinyl-Sepharose 4B; CPD-M $\mathrm{M}_{\mathrm{II}}=$ malt carboxypeptidase III; DFP = diisopropyl phosphorofluoridate; $\mathrm{E}=$ enzyme; $\mathrm{EDTA}=$ ethylenediamine tetraacetic acid, sodium sait; $\mathrm{Et}-\mathrm{Hg}-\mathrm{Cl}$ = ethylmercuric chloride; $\mathrm{FA}$ $=$ furylacryloyl; GYBS-Sepharose $=[(\mathrm{N}$-glycyl-L-tyrosine $)$-p-azo-benzyl $]$ succinyl-Sepharose 4B; $\mathrm{Me}-\mathrm{Hg}-\mathrm{I}=$ methylmercuric iodide; Mes = 2-(N-morpholino)ethane sulfonic acid; $\mathrm{Ph}-\mathrm{Hg}-\mathrm{Cl}=$ phenylmercuric chloride; p-HMB = parahydroxymercuribenzoate; SDS = sodium dodecyl sulfate, $\mathrm{Z}=$ carbobenzoxy. Other abbreviations of amino acids, amino acid derivatives and peptides are according to the guidelines of the IUPAC-IUB Commission on Biochemical Nomenclature. The binding site notation for the enzyme is that of SCHECHTER and BERGER (21). Accordingly, the binding site for the C-terminal amino acid residue of the substrate is denoted $S_{1}^{\prime}$ and those for the amino acid residues in the amino-terminal direction away from the scissile bond are denoted $S_{1}, S_{2} \ldots . ., S_{1}$. The substrate positions are denoted $\mathrm{P}_{\mathrm{i}}^{3}, \mathrm{P}_{1}, \mathrm{P}_{2}, \ldots . \mathrm{P}_{\mathrm{i}}$ in correspondence with the binding sites. 


\section{MATERIALS AND METHODS}

\subsection{Materials}

Malted Grit barley was obtained from United Breweries, Denmark, and D,L-benzylsuccinic acid from Burdick and Jackson, USA. All Z-Ala$\mathrm{X}-\mathrm{OH}$ and $\mathrm{Bz}-\mathrm{Y}-\mathrm{OMe}$ substrates were from Bachem, Switzerland. Sepharose 4B was from Pharmacia Fine Chemicals, Sweden and MeHg-I was from Koch-Light Laboratories, England. Mes and Hepes were purchased from Sigma, USA, and $\left(1,3-{ }^{3} \mathrm{H}\right)$ diisopropyl phosphorofluoridate was a product of Amersham International, England. All other reagents and solvents were of analytical purity and obtained from Merck, W. Germany.

The following materials were prepared as previously described: CABS-Sepharose (2), GYBS-Sepharose (16), FA-Phe-Ala-OH (5), FAAla-Phe-OH (26) and FA-Ala-OBzl (5).

\subsection{Methods}

\subsubsection{Routine determination of enzymatic} activity and protein concentration

Carboxypeptidase activity was routinely assayed at $25^{\circ} \mathrm{C}$ by following the hydrolysis of FA-Phe-Ala-OH and FA-Ala-Phe-OH spectrophotometrically at $337 \mathrm{~nm}$ using a Cary Model 219. The following assay mixture was used: $25 \mu \mathrm{l} 8 \mathrm{mM}$ substrate dissolved in methanol was added to $965 \mu \mathrm{l} 0.1 \mathrm{M}-\mathrm{Mes}, 1$ mM-EDTA, $\mathrm{pH} 4.7$ (the established $\mathrm{pH}$ optimum of the purified enzyme), followed by $10 \mu 1$ enzyme solution. When the $\mathrm{pH}$ of the enzyme solution exceeded 5.5 it was necessary to add the $10 \mu$ l enzyme solution to the assay buffer and wait at least three minutes for the enzyme to equilibrate before addition of the $25 \mu \mathrm{l}$ substrate. One unit was defined as the amount of enzyme necessary to release one micromole of alanine or phenylalanine per min at $25^{\circ} \mathrm{C}$.

Protein concentration was determined spectrophotometrically at $280 \mathrm{~nm}$ using $\mathrm{A}_{280}(1 \%)=$ 20 , determined from amino acid composition and sugar content of the pure enzyme. This value was also used at purification steps where the enzyme was not pure.

\subsubsection{Purification of CPD-M $M_{I I I}$}

$25 \mathrm{~kg}$ of malted Grit barley was ground and suspended in $200 \mathrm{I}$ demineralized water and $\mathrm{pH}$ was adjusted to 3.7 by slow addition of approximately 41 glacial acetic acid. The mixture was stirred for 1 hour at $18-22^{\circ} \mathrm{C}$ and then left for 16 hours at $2{ }^{\circ} \mathrm{C}$ to permit insoluble material to settle. The supernatant, approximately $140 \mathrm{l}$, was concentrated approximately 15 fold by ultrafiltration, and $230 \mathrm{~g}$ ammonium sulfate per liter concentrate was added (38\% saturation). After 16 hours at $4{ }^{\circ} \mathrm{C}$ the precipitate was removed by centrifugation and to the supernatant was added $190 \mathrm{~g}$ ammonium sulfate per liter (65\% saturation). After 16 hours at $4{ }^{\circ} \mathrm{C}$ the resultant suspension was centrifuged yielding a precipitate which could be stored at $4{ }^{\circ} \mathrm{C}$ for at least 2 weeks without loss of enzymatic activity. The further purification of the enzyme was performed in three steps using ion exchange and affinity chromatography.

Step 1: The $65 \%$ ammonium sulfate precipitate was dissolved in 61 water, concentrated to 11 using ultrafiltration equipment from Millipore and then dialysed against $20 \mathrm{~mm}-\mathrm{NaH}_{2} \mathrm{PO}_{4}, \mathrm{pH}$ 6.7. This sample was applied to a DE-52 cellulose column $(10 \times 34 \mathrm{~cm})$ and washed with 20 mM- $\mathrm{NaH}_{2} \mathrm{PO}_{4}, \mathrm{pH} 6.7$ as described by MikolA $(17,18,19)$. CPD-M $\mathrm{III}_{\mathrm{II}}$ eluted in the breakthrough peak whereas essentially all of carboxypeptidases I and II were bound to the column.

Step 2: The breakthrough peak from Step 1 was adjusted to $0.05 \mathrm{M}-\mathrm{NaH}_{2} \mathrm{PO}_{4}, 0.2 \mathrm{M}-\mathrm{NaCl}, \mathrm{pH}$ 4.4 by addition of solid $\mathrm{NaH}_{2} \mathrm{PO}_{4}$ and $\mathrm{NaCl}$, followed by adjustment of $\mathrm{pH}$ by addition of 1 $\mathrm{M}-\mathrm{HCl}$. This sample was applied to a GYBS-Sepharose column $(5 \times 10 \mathrm{~cm})$, equilibrated with $0.05 \mathrm{M}-\mathrm{NaH}_{2} \mathrm{PO}_{4}, 0.1 \mathrm{M}-\mathrm{NaCl}, \mathrm{pH}$ 4.4. The column was washed with approximately 410.05 $\mathrm{M}-\mathrm{NaH}_{2} \mathrm{PO}_{4}, 0.5 \mathrm{M}-\mathrm{NaCl}, \mathrm{pH} 4.4$ until $\mathrm{A}_{280}$ of the eluate was below 0.05 . The enzyme was eluted with $0.05 \mathrm{M}-\mathrm{NaH}_{2} \mathrm{PO}_{4}, 0.1 \mathrm{M}-\mathrm{NaCl}, \mathrm{pH}$ 6.4 .

Step 3: The eluate from Step 2 was adjusted to $\mathrm{pH} 4.4$ by addition of $1 \mathrm{M}-\mathrm{HCl}$ and applied to a GYBS-Sepharose column $(2.6 \times 3.5 \mathrm{~cm})$, equilibrated with $0.05 \mathrm{M}-\mathrm{NaH}_{2} \mathrm{PO}_{4}, 0.1 \mathrm{M}-\mathrm{NaCl}, \mathrm{pH}$ 4.4. The column was washed with approximately 1.51 of the same buffer until $A_{280}$ was below 0.01 . The elution was accomplished with 5 mM-BS, $0.05 \mathrm{NaH}_{2} \mathrm{PO}_{4}, 0.1 \mathrm{M}-\mathrm{NaCl}, \mathrm{pH} 4.4$. The active fractions with $\mathrm{A}_{280}$ above 0.04 were 
concentrated by ultrafiltration using equipment and a YM 10 membrane from Amicon. After dialysis against $0.02 \mathrm{M}$-sodium acetate, $0.2 \mathrm{M}$ $\mathrm{NaCl}, \mathrm{pH} 4.3$ the enzyme was frozen at $-18^{\circ} \mathrm{C}$.

\subsubsection{Homogeneity and molecular weight}

The homogeneity and molecular weight of denatured CPD-M $\mathrm{M}_{\mathrm{II}}$, with and without reduction with dithiothreitol, was determined by SDS gel electrophoresis in $1 \mathrm{~mm}$ thick $7.5 \%$ slab gels with the SDS-phosphate continuous buffer system (25). A Pharmacia gel electrophoresis apparatus GE-2/4 LS was used. The molecular weight of the native enzyme was determined by HPLC gel filtration, using a Protein Pak 300 SW column, equilibrated with $50 \mathrm{~mm}-\mathrm{NaH}_{2} \mathrm{PO}_{4}, \mathrm{pH}$ 7 , and other equipment from Waters Associates.

\subsubsection{Chemical composition}

Samples were hydrolyzed in $6 \mathrm{M}-\mathrm{HCl}$ at 110 ${ }^{\circ} \mathrm{C}$ in vacuo for 24,48 and 72 hours. The evaporated hydrolysates were analyzed on a Durrum D-500 amino acid analyzer. Tryptophan contents were estimated by the method of GOODWIN and MORTON (12). Half-cystine was determined as cysteic acid after performic acid oxidation (14). Free thiol groups were determined by reaction with $\mathrm{p}-\mathrm{HMB}$ in 10 $\mathrm{mM}-\mathrm{NaH}_{2} \mathrm{PO}_{4} \mathrm{pH} 7.0$ (20).

An approximate estimation of the carbohydrate content was obtained by means of the phenol-sulfuric acid method of Dubors et al. (10), using glucose as standard. The content of hexosamine was determined on the amino acid analyzer after hydrolysis for 5,8 and 17 hours in $6 \mathrm{M}-\mathrm{HCl}$ at $110^{\circ} \mathrm{C}$ in vacuo. Glucosamine hydrochloride was used as standard. N-terminal amino acid sequence determination was attempted using a Beckman $890 \mathrm{C}$ liquid phase sequencer.

\subsubsection{Stability of $C P D-M_{I I I}$}

The stability of CPD-M $\mathrm{M}_{\mathrm{HI}}$ was investigated by incubating the enzyme $\left(0.04 \mathrm{mg} \cdot \mathrm{ml}^{-1}\right)$ at $25^{\circ} \mathrm{C}$ in the following buffers containing $0.1 \mathrm{M}-\mathrm{NaCl}$ and 1 mM-EDTA: 0.05 M-sodium formate, $\mathrm{pH}$ 2.5 and 3.0;0.05 $\mathrm{M}$-sodium acetate, $\mathrm{pH} 3.6$ and
4.5; 0.05 M-Mes, pH 5.0 and 6.7; 0.05 M-Hepes, pH 7.5, 8.0 and 8.6. The activity towards FAAla-Phe-OH (see section 2.2.1) was followed as a function of time.

\subsubsection{Inhibition studies}

Modification of CPD-M $\mathrm{M}_{\text {III }}$ with DFP was performed in the following manner: $5 \mu \mathrm{l}\left({ }^{3} \mathrm{H}\right)$ DFP (1.2 $\mathrm{mM}$ in propylene glycol) was added to 240 $\mu \mathrm{l} 50 \mathrm{~mm}-\mathrm{Na}_{2} \mathrm{HPO}_{4}, 0.2 \mathrm{M}-\mathrm{NaCl}, \mathrm{pH} 7.0$, containing $0.20 \mathrm{mg}$ enzyme $\cdot \mathrm{ml}^{-1}$, i.e. the concentration of enzyme was $4.2 \mu \mathrm{M}$ and the concentration of reagent was $24 \mu \mathrm{M}$. The enzymatic activity, using the assay described in section 2.2.1, was followed as a function of time.

The influence of mercurials on the activity of CPD-M $\mathrm{M}_{\mathrm{II}}$ was studied in the following way: $50 \mu \mathrm{l}$ enzyme $(0.43 \mathrm{mg} / \mathrm{ml})$ was added to $50 \mu 10.2$ M-Mes, $\mathrm{pH} 6.0$ followed by $5 \mu \mathrm{l}$ of either $\mathrm{HgCl}_{2}$, $\mathrm{Ph}-\mathrm{Hg}-\mathrm{Cl}$, Et-Hg-Cl or Me-Hg-I (0.025-0.2 $\mathrm{mm}$ ). The solutions of $\mathrm{Ph}-\mathrm{Hg}-\mathrm{Cl}, \mathrm{Et}-\mathrm{Hg}-\mathrm{Cl}$ and Me-Hg-I were diluted in water from a $10 \mathrm{~mm}$ solution in dimethylformamide. After incubation for 15 minutes the enzyme was assayed in the following manner: $10 \mu \mathrm{l}$ enzyme was added to $965 \mu 10.1 \mathrm{M}-\mathrm{Mes}, \mathrm{pH} 6.0$, and after incubation for 5 minutes, $25 \mu \mathrm{l} 8 \mathrm{~mm}$ substrate (FA-Ala$\mathrm{OBzl}$ ) in methanol was added.

\subsubsection{Enzymatic properties of CPD-M $M_{m}$}

The specificity of CPD-M $\mathrm{M}_{11 !}$ was investigated by determination of $\mathrm{k}_{\mathrm{cta}} / \mathrm{K}_{\mathrm{m}}$ values for the hydrolysis of a series of Z-Ala-X-OH and Bz-YOMe substrates $(X$ and $Y=$ amino acid residues). $10 \mu 1$ enzyme solution was added to $965 \mu \mathrm{l} 0.1 \mathrm{M}-\mathrm{Mes}, 0.1 \mathrm{M}-\mathrm{NaCl}, 1 \mathrm{~mm}-\mathrm{EDTA}, \mathrm{pH}$ 4.7 for the Z-Ala-X-OH substrates and 0.1 M-Mes, $0.1 \mathrm{M}-\mathrm{NaCl}, 1 \mathrm{~mm}$-EDTA, pH 5.8 for the Bz-Y-OMe substrates. $25 \mu$ l of a $20 \mathrm{~mm}$ substrate solution in methanol or water was added and, after mixing, the hydrolysis was followed spectrophotometrically to completion on a Cary 219 spectrophotometer at $25^{\circ} \mathrm{C}$ as a decrease in absorbance at $230 \mathrm{~nm}$ for the Z-Ala-X-OH substrates and as an increase in absorbance at $254 \mathrm{~nm}$ for the Bz-Y-OMe substrates. The $\mathrm{k}_{\mathrm{ca}} / \mathrm{K}_{\mathrm{m}}$ values were determined from the integrated form of the Michaelis-Menten equation (22). 
Table 1. Purification of CPD-M

\begin{tabular}{|c|c|c|c|c|c|c|c|c|c|}
\hline & \multirow[b]{2}{*}{$\mathrm{ml}$} & \multirow[b]{2}{*}{$\mathrm{mg} / \mathrm{ml}$} & \multicolumn{3}{|c|}{ FA-Ala-Phe-OH } & \multicolumn{3}{|c|}{ FA-Phe-Ala-OH } & \multirow{2}{*}{$\begin{array}{l}\text { FA-Ala- } \\
\text { Phe-OH } \\
\text { FA-Phe- } \\
\text { Ala-OH }\end{array}$} \\
\hline & & & $\mathrm{U} / \mathrm{ml}$ & $\mathrm{U}_{\text {TOTAL }}$ & $\mathrm{U} / \mathrm{mg}$ & $\mathrm{U} / \mathrm{ml}$ & $\mathrm{U}_{\text {TOTAL }}$ & $\mathrm{U} / \mathrm{mg}$ & \\
\hline Concentrated extract & 7500 & 42 & 2.8 & 21000 & 0.033 & 7.7 & 58000 & 0.092 & 0.36 \\
\hline $\begin{array}{l}\text { Sample applied } \\
\text { to DE } 52\end{array}$ & 2500 & 23 & 6.3 & 16000 & 0.13 & 14 & 35000 & 0.30 & 0.45 \\
\hline $\begin{array}{l}\text { Breakthrough fraction } \\
\text { from } D E 52\end{array}$ & 1800 & 8 & 0.57 & 1000 & 0.035 & 0.47 & 850 & 0.029 & 1.2 \\
\hline $\begin{array}{l}\text { Eluate from first } \\
\text { affinity column }\end{array}$ & 250 & 0.17 & 2.0 & 500 & 12 & 0.61 & 150 & 3.6 & 3.3 \\
\hline $\begin{array}{l}\text { Concentrated and } \\
\text { dialysed eluate from } \\
\text { second affinity column }\end{array}$ & 9 & 0.27 & 13 & 117 & 48 & 2.3 & 21 & 8.5 & 5.7 \\
\hline
\end{tabular}

The $\mathrm{k}_{\mathrm{cat}}$ and $\mathrm{K}_{\mathrm{m}}$ values for the hydrolysis of FA-Ala-Phe-OH and FA-Ala-OBzl were determined, from Lineweaver-Burk plots, as a function of $\mathrm{pH}$ using the following buffers containing $0.2 \mathrm{M}-\mathrm{NaCl}$ and $1 \mathrm{~mm}$-EDTA: $0.1 \mathrm{M}$-sodium formate, $\mathrm{pH} 3.5-4.5 ; 0.1 \mathrm{M}-\mathrm{Mes}, \mathrm{pH} 4.5-6.9 ; 0.1$ $\mathrm{M}-\mathrm{Hepes}, \mathrm{pH} 7-7.5$. The rates of hydrolysis were determined spectrophotometrically at 329-337 nm at $25^{\circ} \mathrm{C}$.

\section{RESULTS}

\subsection{Purification of CPD-M $\mathrm{M}_{\mathrm{III}}$}

No specific assay for $\mathrm{CPD}-\mathrm{M}_{\mathrm{III}}$ has been found; all substrates of this enzyme are also hydrolyzed by carboxypeptidases I and II. However, $C P D-M_{I I I}$ is characterized by a FA-Ala-Phe$\mathrm{OH} / \mathrm{FA}-\mathrm{Phe}-\mathrm{Ala}-\mathrm{OH}$ ratio of 5.7 whereas it is only 0.07 for carboxypeptidase I and 0.3 for carboxypeptidase II. This ratio was consequently utilized to monitor the purification of CPD$\mathrm{M}_{\mathrm{II}}$. The ammonium sulfate precipitate is characterised by a FA-Ala-Phe-OH/FA-Phe-Ala-OH of 0.5 (Table I), but the breakthrough fraction from the ion exchange chromatography on $\mathrm{DE}$ Cellulose of the dialysed crude ammonium sulfate precipitate is characterized by a ratio of 1.2 , indicating that this chromatographic step to some extent has separated CPD-M $\mathrm{M}_{\mathrm{III}}$ from car- boxypeptidases I and II in accordance with the observations by Mikola $(17,18,19)$. A further increase in this ratio was obtained by the two step affinity chromatographic procedure utilizing GYBS-Sepharose (Table I). The elution in the first step was accomplished by a $\mathrm{pH}$ change and in the second step by including the inhibitor BS in the washing buffer.

\subsection{Physical-chemical characterization of CPD-M $\mathrm{M}_{\text {III }}$}

SDS gel electrophoresis of CPD-M $\mathrm{M}_{\mathrm{II}}$ in the presence and in the absence of dithiothreitol revealed a single band with a mobility corresponding to a molecular weight of 48,000 , indicating that the enzyme is a single peptide chain. The HPLC gel filtration also indicated that the enzyme had a molecular weight of approximately 48,000 . The enzyme did not react with Edman's reagent, suggesting that it is $\mathrm{N}$-terminally blocked. The amino acid composition of CPD$\mathbf{M}_{\text {III }}$ is listed in Table II. It contains a single free sulfhydryl group, as determined with p-HMB, as well as two residues of glucosamine and $2 \%$ neutral sugar.

CPD-M $\mathrm{M}_{1 ! I}$ was stable at $25^{\circ} \mathrm{C}$ for four hours at $\mathrm{pH}$ values between 3.0 and 7.5. At $\mathrm{pH} 2.5,8.0$ and 8.6 the enzyme lost its activity with $t_{1 / 2}$ values of 4,31 and 3 minutes, respectively. 
Table II. Amino acid composition of CPD-M

\begin{tabular}{lc}
\hline Amino acid & Residues per 48,000 \\
\hline Asp & 52.0 \\
Thr ${ }^{\text {a) }}$ & 19.2 \\
Ser $^{\text {a) }}$ & 27.4 \\
Glu & 37.6 \\
Pro & 17.7 \\
Gly & 39.4 \\
Ala & 33.0 \\
Val & \\
Met & 25.8 \\
Ile & 12.0 \\
Leu & 22.9 \\
Phe & 33.4 \\
Tyr & 19.6 \\
His & 29.4 \\
Lys & 12.7 \\
Arg & 23.9 \\
Cys & 17.1 \\
Trp & 9 \\
Glucosamine & 8 \\
Neutral sugar & $2 \%$ \\
\hline
\end{tabular}

The experimental values were based on the average of two amino acid analysis after hydrolysis in $6 \mathrm{M}-\mathrm{HCl}$ for 24,48 , and 72 hours. The content of glucosamine was based on analysis after 5, 8 and 17 hours of hydrolysis. a) Extrapolated to zero time. b) Value after 72 hours of hydrolysis. ${ }^{c)}$ Determined as cysteic acid after performic acid oxidation. d) Determined spectrophotometrically by the method of GOODWIN and MORTON (12). " Determination by the method of DuBoIs et al. (10).

\subsection{Enzymatic properties of CPD- $\mathrm{M}_{\mathrm{III}}$}

The routine assay of CPD-M $\mathrm{M}_{1 \mathrm{II}}$ towards FAAla-Phe-OH, performed at $\mathrm{pH} 4.7$ (see section 2.2), exhibited abnormal kinetics when the enzyme added was preincubated at $\mathrm{pH}$ values above 5.5: a concave progression curve was observed during the first few minutes, indicating that the enzyme was activated during the assay. Conversely, when the enzyme was preincubated at $\mathrm{pH} 4.7$ no such activation was observed. This suggested that the enzyme at $\mathrm{pH}$ values above pH 5.5 exists in a lesser active form and that the transition to the more active form at lower $\mathrm{pH}$ values is time dependent. To test this hypothesis the reverse transition was performed: the en-

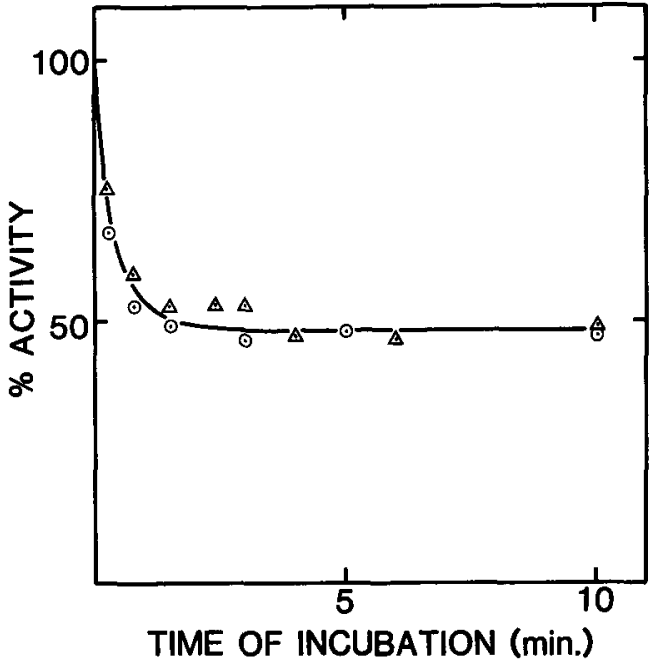

Figure 1. Time dependent change in activity of CPD$\mathrm{M}_{11 \mathrm{I}}$ after shift in $\mathrm{pH}$. The assays were performed under the following conditions: $10 \mu \mathrm{lCPD}-\mathrm{M}_{\mathrm{III}}$ (in $0.1 \mathrm{M}-\mathrm{Mes}$ $0.2 \mathrm{M}-\mathrm{NaCl}, 1 \mathrm{~mm}-\mathrm{EDTA}, \mathrm{pH} 4.5$ ) was added to a cuvette containing $965 \mu \mathrm{l} 0.1 \mathrm{M}-\mathrm{Mes}, 0.2 \mathrm{M}-\mathrm{NaCl}, 1$ mM-EDTA, pH 6.5. At the time indicated $25 \mu 18 \mathrm{~mm}$ FA-Ala-Phe-OH $(\odot)$ or $25 \mu \mathrm{l} 0.8 \mathrm{~mm}$ FA-Ala-OBzl $(\Delta)$ was added and the rate of hydrolysis determined spectrophotometrically (see section 2.2 ).

zyme, preincubated at $\mathrm{pH} 4.5$, was added to a pH 6.5 assay buffer and after various times of incubation the substrate, FA-Ala-OBzl or FAAla-Phe-OH, was added (see Figure 1). During the first 2 minutes of incubation the initial rate of hydrolysis of both substrates decreased to approximately $50 \%$. Longer incubation times had no further effects. All assays were consequently performed after preincubation for three minutes to allow the enzyme to enter the form characteristic of the conditions of the assay.

The $\mathrm{pH}$ dependence of the peptidase and esterase activities of CPD-M $\mathrm{M}_{\mathrm{II}}$ was investigated with the substrates FA-Ala-Phe-OH and FA-AlaOBzl, respectively (Figure 2). For both substrates $\mathbf{k}_{\text {cat }}$ increased with $\mathrm{pH}$ and reached a maximum at $\mathrm{pH} 5.5-6.0$ and again declined above $\mathrm{pH} 6$. The $\mathrm{pH}$ dependence of $\mathrm{K}_{\mathrm{m}}$ for the two substrates differed slightly: $\mathrm{K}_{\mathrm{m}}$ for the hydrolysis of FA-AlaPhe-OH increased slightly in the $\mathrm{pH}$ range 3.3 5.5 and sharply above $\mathrm{pH} 5.5$, whereas $\mathrm{K}_{\mathrm{m}}$ for the hydrolysis of Fi-Ala-OBzl was constant in 


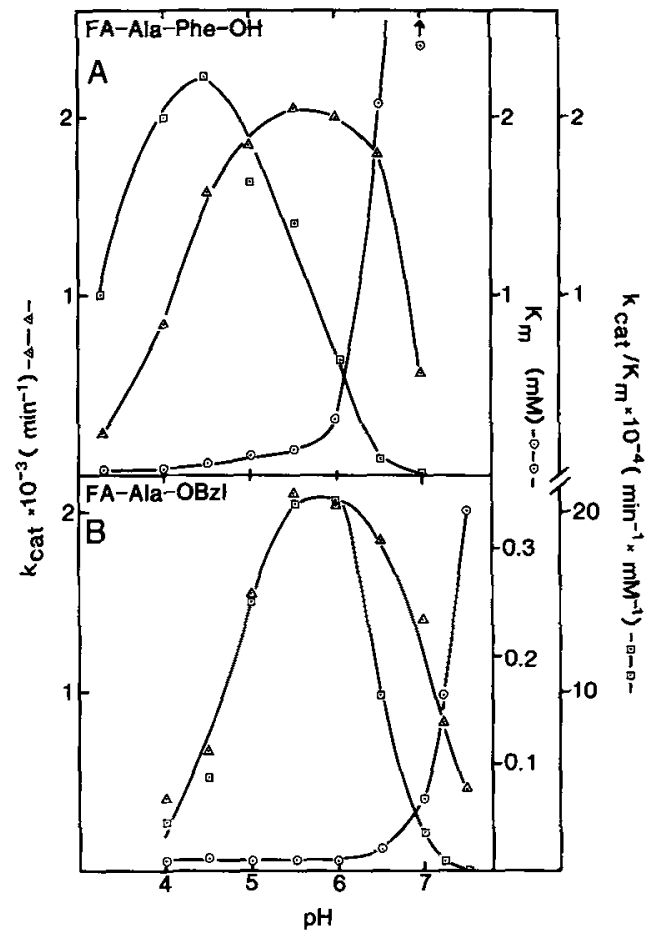

Figure 2. Influence of $\mathrm{pH}$ on the kinetic parameters for the CPD-M $\mathrm{M}_{\mathrm{II}}$ catalyzed hydrolysis of FA-Ala-Phe-OH (A) and FA-Ala-OBzl (B). The assays were performed in $0.1 \mathrm{M}$ buffer, $0.1 \mathrm{M}-\mathrm{NaCl}, 1 \mathrm{mM}$-EDTA. The mixture contained $2.5 \% \mathrm{CH}_{3} \mathrm{OH}$. The buffers employed are listed in section 2.2 .

the $\mathrm{pH}$ range $4-6$ and increased sharply above $\mathrm{pH}$ 6.5. This different effect of $\mathrm{pH}$ on $\mathrm{K}_{\mathrm{m}}$ with the two substrates explain why $k_{\text {cat }} / K_{m}$ for the hydrolysis of FA-Ala-Phe-OH is maximal at $\mathrm{pH}$ 4.5 while for FA-Ala-OBzl it is maximal at $\mathrm{pH}$ 5.8. High $\mathrm{K}_{\mathrm{m}}$ values precluded determinations at $\mathrm{pH}$ values above 7.0 for FA-Ala-Phe-OH and 7.5 for FA-Ala-OBzl.

The substrate preference of CPD-M $\mathrm{M}_{\mathrm{III}}$ with respect to the $P_{1}^{\prime}$ position of peptide substrates was determined at $\mathrm{pH} 4.7$, using a series of $\mathrm{Z}-\mathrm{Ala}-\mathrm{X}-\mathrm{OH}$ substrates and that with respect to the $P_{1}$ position of ester substrates was determined using a series of Bz-Y-OMe substrates at $\mathrm{pH}$ 5.8. The results are listed in Table III and compared with the corresponding data for malt carboxypeptidases I and II and carboxypeptidase $Y$. Listing the results with $C P D-M_{11}$ in
Table III. Hydrolysis of Z-Ala-X-OH and Bz-Y-OMe substrates ( $X$ and $Y=$ amino acid residue) with serine carboxypeptidases

\begin{tabular}{|c|c|c|c|c|}
\hline \multirow[b]{2}{*}{ Substrate } & \multicolumn{4}{|c|}{$\mathrm{k}_{\mathrm{cal}} / \mathrm{K}_{\mathrm{m}}\left(\mathrm{min}^{-1} \cdot \mathrm{mM}^{-1}\right)$} \\
\hline & $\begin{array}{c}\text { CPD- } \\
\mathrm{M}_{1}\end{array}$ & $\begin{array}{c}\text { CPD- } \\
M_{\mathrm{II}}\end{array}$ & $\begin{array}{c}\text { CPD- } \\
\mathbf{M}_{\text {[II }}\end{array}$ & $\begin{array}{c}\text { CPD- } \\
Y\end{array}$ \\
\hline Z-Ala-Gly-OH & 480 & 11 & 11 & $<30$ \\
\hline Z-Ala-Ala-OH & 22000 & 560 & 2100 & 13000 \\
\hline Z-Ala-Val-OH & 35000 & 1800 & 17000 & 15000 \\
\hline Z-Ala-Ile-OH & 22000 & 3300 & 27000 & 32000 \\
\hline Z-Ala-Met-OH & 18000 & 3200 & 43000 & 56000 \\
\hline Z-Ala-Phe-OH & 5700 & 2100 & 94000 & 19000 \\
\hline Z-Ala-Pro-OH & 2600 & 6 & 120 & 370 \\
\hline Z-Ala-Asp-OH & 370 & 71 & $<1$ & $<30$ \\
\hline Z-Ala-Asn-OH & 270 & 62 & $<1$ & 520 \\
\hline Z-Ala-Lys-OH & $<5$ & 25000 & 7 & 520 \\
\hline Z-Ala-Arg-OH & $<5$ & 18000 & 9 & 2000 \\
\hline Z-Ala-His-OH & 120 & 1100 & 1 & 190 \\
\hline Z-Ala-Ser-OH & 1080 & 150 & 5 & 1700 \\
\hline $\mathrm{Bz}-\mathrm{Gly}-\mathrm{OMe}$ & $<5$ & $<5$ & $<1$ & 3 \\
\hline $\mathrm{Bz}-\mathrm{Ala}-\mathrm{OMe}$ & 370 & 19 & 200 & 490 \\
\hline $\mathrm{Bz}$-Val-OMe & 22 & 7 & 35 & 180 \\
\hline Bz-Ile-OMe & 17 & 8 & 34 & 260 \\
\hline Bz-Leu-OMe & 420 & 310 & 820 & 5600 \\
\hline Bz-Met-OMe & 1200 & 160 & 750 & 2800 \\
\hline Bz-Phe-OMe & 14600 & 5700 & 1000 & 51000 \\
\hline $\mathrm{Bz}-\mathrm{Asp}-\mathrm{OMe}$ & $<5$ & $<5$ & 2 & $<1$ \\
\hline Bz-Lys-OMe & 18300 & 2200 & 3 & 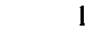 \\
\hline $\mathrm{Bz}-\mathrm{Arg}-\mathrm{OMe}$ & 25300 & 950 & 18 & 12 \\
\hline Bz-His-OMe & 5600 & 76 & 23 & 13 \\
\hline $\mathrm{Bz}-\mathrm{Thr}-\mathrm{OMe}$ & 69 & $<5$ & 5 & 18 \\
\hline Bz-Pro-OMe & $<5$ & $<5$ & $<1$ & $<1$ \\
\hline
\end{tabular}

Assay conditions: $0.5 \mathrm{~mm}$ substrate, $2.5 \% \mathrm{CH}_{3} \mathrm{OH}, 0.1$ M-Mes, 1 mM-EDTA pH 4.7 for Z-substrates and $\mathrm{pH}$ 5.8 for Bz-substrates. The rate of hydrolysis was measured spectrophotometrically at $230 \mathrm{~nm}$ for $\mathrm{Z}$ substrates and $254 \mathrm{~nm}$ for Bz-substrates. The reaction was fol-lowed to more than $95 \%$ completion. From the progres- sion curves $k_{\mathrm{cal}} / \mathrm{K}_{\mathrm{m}}$ values were determined utilizing the integrated form of the Michaelis-Menten equation. The values for malt carboxypeptidase $\mathrm{II}$ are based on a molecular weight of 48.000 . The values for carboxypeptidases I, II and Y are from refs. 1, 2, 3, 6 and 7.

decreasing order of $k_{\text {cat }} / K_{m}$ the following influence of residue $\mathrm{X}$ was observed: Phe $>$ Met $>$ Ile $>$ Val $\gg$ Ala $\gg$ Pro $\gg$ Gly, Ser, Arg, Lys $>$ Asn, Asp, His and of residue Y: Phe, Leu, Met $>$ Ala $>$ Val, Ile, His, Arg > Thr, Lys, Asp > Gly, Pro. 


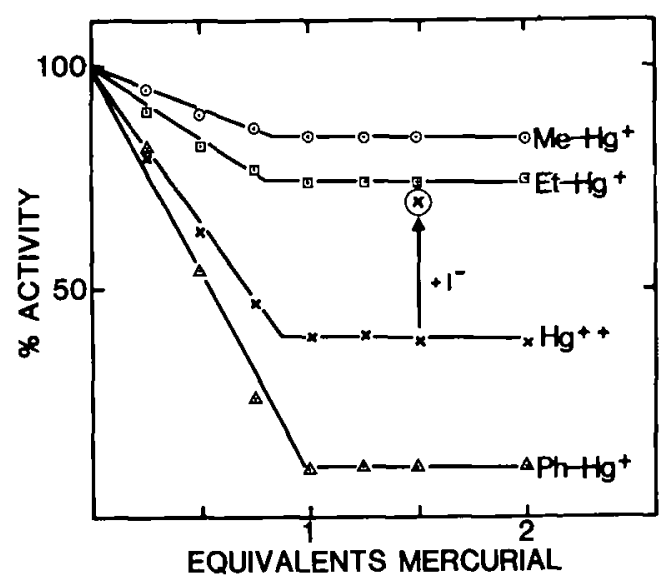

Figure 3. Inhibition of CPD-M $\mathrm{M}_{\text {III }}$ with mercurials. The enzyme was incubated 15 minutes at $25^{\circ} \mathrm{C}$ with the amount of mercurial indicated and then assayed with FA-Ala-OBzl as substrate (see section 2.2).

The activity of CPD-M $\mathrm{M}_{\mathrm{II}}$ towards FA-AlaPhe-OH was completely abolished after 3 hours reaction with DFP. CPD-M $\mathrm{M}_{\mathrm{II}}$ was inhibited by various mercurials (Figure 3 ). In all cases the activity towards FA-Ala-OBzl decreased linearly with increasing concentrations of mercurials until maximal inactivation was reached at approximately equimolar concentrations. The residual activity with $\mathrm{Me}-\mathrm{Hg}^{+}, \mathrm{Et}-\mathrm{Hg}^{+}, \mathrm{Hg}^{++}$and $\mathrm{Ph}-\mathrm{Hg}^{+}$as reagents was $74 \%, 64 \%, 39 \%$ and $11 \%$ of the control, respectively. Inclusion of $10^{-4}$ $\mathrm{M}-\mathrm{KI}$ in the assay medium increased the level of residual activity of the $\mathrm{Hg}^{++}$modified enzyme from $33 \%$ to $70 \%$, but had no influence on the activities of the enzymes modified with $\mathrm{Me}-\mathrm{Hg}^{+}$, $\mathrm{Et}-\mathrm{Hg}^{+}$and $\mathrm{Ph}-\mathrm{Hg}^{+}$.

\section{DISCUSSION}

The purification procedure for CPD-M $\mathrm{M}_{11 \mathrm{II}}$ resembles the earlier described procedures for malt carboxypeptidases I and II $(2,6)$. It was found convenient, although not strictly necessary, to separate CPD-M $\mathrm{M}_{\mathrm{III}}$ from the bulk of carboxypeptidases I and II by ion exchange chromatography as previously described $(17,18$, 19) before the affinity chromatographic purification. CPD-M $\mathrm{M}_{\mathrm{II}}$ exhibited very little affinity for the CABS-Sepharose resin, previously utilized for isolation of carboxypeptidases I and II $(2,6)$. However, it exhibited high affinity for GYBSSepharose, in contrast to carboxypeptidase I, permitting the isolation of CPD-M $\mathrm{M}_{\mathrm{III}}$ from the break-through fraction of the ion exchange column. Both GYBS-Sepharose and CABS-Sepharose contain the BS ligand but on different spacer arms.

CPD-M $\mathrm{M}_{\mathrm{III}}$ is inhibited by DFP and thus, belongs to the class of serine carboxypeptidases like the two other carboxypeptidases from malt $(2,6)$. However, CPD-M $\mathrm{M}_{\mathrm{III}}$ is a monomeric enzyme, consisting of a single peptide chain while malt carboxypeptidases I and II are dimeric with each monomer consisting of two peptide chains, linked by disulfide bridges $(2,6,23,24)$. Furthermore, CPD-M $\mathrm{M}_{\mathrm{III}}$ contains far less carbohydrate than the other two carboxypeptidases.

The esterase and peptidase activities of CPD$\mathrm{M}_{\mathrm{III}}$ are both dependent on the deprotonation of a group with a $\mathrm{pK}_{\mathrm{a}}$ around 4.5 and this value is normal within the group of serine carboxypeptidases. However, in the basic $\mathrm{pH}$ range the enzyme differs from the other enzymes within the group. CPD-M $\mathrm{M}_{\mathrm{II}}$ exists in an active acidic form and an inactive basic form, controlled by the ionic state of a group with a $\mathrm{pK}_{\mathbf{a}}$ around 7 . The transition between the two forms is time dependent, suggesting the involvement of a conformational change. The serine carboxypeptidases previously described also hydrolyse peptides with low rates at basic $\mathrm{pH}$ due to poor binding of such substrates (8). This has been attributed to deprotonation of a positively charged group which at acidic $\mathrm{pH}$ functions as binding site for the C-terminal carboxylate group of peptide substrates. However, these enzymes retain the activity towards substrates with blocked C-terminus, i.e. peptide esters and peptide amides, and thus, these enzymes do not enter an inactive conformation at basic $\mathrm{pH}(8)$.

In chymotrypsin the activity varies similarly to that of CPD-M $\mathrm{M}_{11}$ : the positively charged $\alpha$-ammonium group of Ile-16 forms an ion pair with the carboxylate group of Asp-194, maintaining the enzyme in an active conformation (13). At $\mathrm{pH}>8.5$ the ammonium group is deprotonated and the enzyme instantaneously enters an inactive conformation. 
The specificities of malt carboxypeptidases I, II and III supplement each other. With respect to the C-terminal position carboxypeptidase I exhibits a preference for amino acid residues with uncharged aliphatic side-chains (2), carboxypeptidase II prefers amino acid residues with positively charged side-chains (6), and CPD-M $\mathrm{M}_{\text {III }}$ prefers amino acid residues with aromatic side-chains. With respect to the penultimate position, carboxypeptidases I and II exhibit preferences for amino acid residues with positively charged and aromatic side-chains (3, 7) while CPD-M $M_{\text {III }}$ prefers amino acid residues with aromatic and uncharged aliphatic sidechains without branched $\beta$-carbon. The specificity of CPD-M $\mathrm{M}_{\mathrm{III}}$ is similar to that of carboxypeptidase $\mathrm{Y}$ with the exception that carboxypeptidase $\mathrm{Y}$ exhibits a much more pronounced preference for aromatic residues at the penultimate position (1) than does CPD-M $\mathrm{M}_{\mathrm{III}}$.

CPD-M $\mathrm{M}_{\text {III }}$ contains an unblocked -SH group which may be modified with one equivalent of $\mathrm{Hg}^{++}, \mathrm{Ph}-\mathrm{Hg}^{+}, \mathrm{Me}-\mathrm{Hg}^{+}$, or Et- $\mathrm{Hg}^{+}$with the result that the enzyme is partially inactivated. Malt carboxypeptidase II contains no unblocked -SH group (6) and the one in carboxypeptidase $I$ is not reactive towards mercurials (2). However, the $-\mathrm{SH}$ group of CPD-M $\mathrm{M}_{\mathrm{II}}$ exhibits a reactivity similar to that of carboxypeptidase $\mathrm{Y}$ (Cys-341) (1) and that of the carboxypeptidase from Penicillium janthinellum (15). As in the case of carboxypeptidase $Y$ the extent of inactivation of CPD-M $\mathrm{M}_{\mathrm{H}}$ correlates with the bulkiness of the mercurial but in contrast to carboxypeptidase $Y$ no correlation with the bulkiness of the substrate has been observed (results not shown). Thus, it is not possible to assign the unblocked cysteinyl residue of CPD-M $\mathrm{M}_{\mathrm{III}}$ to the substrate binding site. The influence of $\mathrm{I}^{-}$on the activity of the enzyme modified with $\mathrm{Hg}^{++}$is consistent with iodide forming a complex with the enzyme-bound mercuric ion according to the following equilibrium: $\mathrm{E}-\mathrm{Hg}^{+}+\mathrm{I}^{-} \rightleftharpoons \mathrm{E}-\mathrm{Hg}-\mathrm{I}$. Similar effects of $\mathrm{I}^{-}$and other halides were also observed in the case of $\mathrm{Hg}^{++}$modified carboxypeptidase $\mathrm{Y}$ (1).

Chemical modifications of Cys 341 of carboxypeptidase $Y(1,9)$ and its exchange with other amino acid residues by site-directed mutagenesis (26) reduce the activity to approximately $20 \%$. These results, combined with those on
CPD-M $\mathrm{M}_{\text {III }}$, suggest that the -SH group located at the active site of some serine carboxypeptidases has a function although it is not essential to catalysis.

\section{ACKNOWLEDGEMENTS}

Professor MARTIN OTTESEN is thanked for his support and for carefully reading the manuscript. Dr. Iв SVENDSEN is acknowledged for performing the sequence determination. $\mathrm{Mr}$. THORKILD BEENFELDT and Ms. SuSANNE EVALD are acknowledged for excellent technical assistance.

\section{REFERENCES}

1. BREDDAM.K.: Modification of the single sulfhydryl group of carboxypeptidase $Y$ with mercurials. Influence on enzyme specificity. Carlsberg Res. Commun. 48, 9-19 (1983)

2. Breddam, K.. S. Bech Sørensen \& M. OtTesen: Isolation of a carboxypeptidase from malted barley by affinity chromatography. Carlsberg Res. Commun. 48, 217-230 (1983)

3. BREDDAM, $K$ \& $\mathrm{M}$. OtTesen: Influence of guanidine derivatives on the specificity of malt carboxypeptidase I. Carlsberg Res. Commun. 48, 573-582 (1982)

4. BREDDAM, K. \& M. OTTESEN: Malt carboxypeptidase I catalyzed aminolysis reactions. Carlsberg Res. Commun. 49, 473-481 (1984)

5. BREDDAM. K.: Chemically modified carboxypeptidase $\mathrm{Y}$ with increased amidase activity. Carlsberg Res. Commun. 49, 535-554 (1984)

6. Breddam. K., S. Bech Sørensen \& M. Ottesen: Isolation of carboxypeptidase II from malted barley by affinity chromatography. Carlsberg Res. Commun. 50, 199-209 (1985)

7. Breddam. K.: Enzymatic properties of malt carboxypeptidase II in hydrolysis and aminolysis reactions. Carlsberg Res. Commun. 50, 309-323 (1985)

8. BRedDAM. K.: Serine carboxypeptidases. A review. Carlsberg Res. Commun. 51, 83-128 (1986)

9. BredDaM, K., \& A. KanSTRUP: Cyanylation of the single sulfhydryl group in carboxypeptidase $Y$ with cyanogen bromide. Carlsberg Res. Commun. 52, 65-71 (1987)

10. Dubois. M., K. A. Gilles, J. K. Hamilton, P. A. REBERS \& F. SMITH: Colorimetric method for determination of sugar and related substances. Anal. Chem. 38, 350-356 (1956) 
11. ENARI. T. -M.: Break-down of proteins during malting and mashing. EBC-Monograph-IV. EBC-symposium on the relationship between malt and beer. Helsinki-November 1980

12. Goodwin, T.W.\& R. A. MORTON: The spectrophotometric determination of tyrosine and tryptophan in proteins. Biochem. J. 40, 628-632 (1946)

13. Hess, G. P.: Chymotrypsin - chemical properties and catalysis. The Enzymes, 3rd Ed., p. 213-248 (1971)

14. HiRS, C. H. W.: Determination of cystine as cysteic acid. Meth. Enzymol. 11, 59-62 (1967)

15. HofmanN, T.: Penicillocarboxypeptidases S-1 and S-2. Meth. Enzymol. 45, 587-599 (1979)

16. Johansen, J. T., K. BReddaM \& M. OtTesen: Isolation of carboxypeptidase $Y$ by affinity chromatography. Carlsberg Res. Commun. 41, 1-14 (1976)

17. Mikola. L. \& J. Mikola: Mobilization of proline in the starchy endosperm of germinating barley grain. Planta 149, 149-154 (1980)

18. Mikola, L.: Germinating barley grains contain five acid carboxypeptidases with complementary substrate specificities. Biochim. Biophys. Acta 747, 241-252 (1983)

19. MiKOLA. L.: Acid carboxypeptidases in grains and leaves of wheat, Triticum aestivum L. Plant Phys- iol. $81,823-829$ (1986)

20. Riordan, J. F. \& B. L. ValleE: Reactions with $\mathrm{N}$-ethylmaleimide and p-mercuribenzoate. Meth. Enzymol. 25, 449-456 (1972)

21. SCHECHTER, J.\& B. BERGER: On the size of the active site of proteases. I. Papain. Biochem. Biophys. Res. Commun. 27, 157-162 (1967)

22. SEGEL, J. H.: Enzyme Kinetics pp. 227-231, WileyInterscience, New York (1975)

23. Sorensen. S. B.. K. Breddam \& I. Svendsen: Primary structure of carboxypeptidase I from malted barley. Carlsberg Res. Commun. 51, 475-485 (1986)

24. Sørensen, S. B., I. Svendsen \& K. Breddam: Primary structure of carboxypeptidase II from malted barley. Carlsberg Res. Commun. 52, 285-295 (1987)

25. Weber, K., J. R. Pringle \& M. Osbern: Measurement of molecular weights by electrophoresis on SDS-acrylamide gel. Meth. Enzymol, 26, 3-27 (1972)

26. Winther. J. \& K. BRedDam: The free sulfhydryl group (Cys341) of carboxypeptidase Y: Functional effects of mutational substitutions. Carlsberg Res. Commun. 52, 263-273 (1987)

Accepted by S. O. ANDERSEN 